\title{
DISASTER-RELATED DISPLACED SOMALIS AND ETHIOPIANS IN YEMEN
}

\author{
V. KOLMANNSKOG ${ }^{1} \& \mathrm{~T} . \mathrm{AFIFI}^{2}$ \\ ${ }^{1}$ Independent Scholar and Consultant, Norwegian Refugee Council (NRC), Norway. \\ ${ }^{2}$ Associate Academic Officer, United Nations University Institute for Environment \\ and Human Security (UNU-EHS).
}

\begin{abstract}
This article addresses the existing opportunities and protection gaps for Ethiopians and Somalis who had been exposed to and suffering from environmental problems in their home countries and had to flee to Yemen. It suggests policy and legal options in cross-border disaster-related displacement in the Horn of Africa and Middle East regions, with specific focus on Ethiopia and Somalia as sending countries and Yemen as a receiving country. The article provides a number of recommendations, including using a broad socio-legal approach that also considers norms and religious values when dealing with cross-border displaced persons as well as bilateral agreements between the host and sending countries. Keywords: disasters, displacement, Horn of Africa, migrants, prima facie status, protection gaps, refugees, regular and irregular migrants, Yemen.
\end{abstract}

\section{INTRODUCTION}

According to the Intergovernmental Panel on Climate Change (IPCC), climate change can impact on human mobility [1]. According to IDMC [2], around 144 million people were forced to leave their homes due to sudden-onset disasters over the time period between 2008 and 2012, the vast majority of which were affected by floods, storms, wildfires and other hazards that are influenced by climate change. Moreover, other hundreds of thousands of people have to move due to slow-onset disasters, such as drought. People in the Horn of Africa have been severely affected. For example, large numbers of Somalis and Ethiopians fled the droughts throughout 2011 and 2012, seeking assistance, protection and better livelihoods.

Several studies have explored the direct and indirect impact of environmental issues on human mobility in the Horn of Africa region [3-6]. An overall and common outcome is that there are several factors contributing to human mobility, where environmental changes are becoming more visible and influential. Regarding Yemen as a receiving country of Ethiopians and Somalis, there are various studies that report about the background and motivations of the arrivals as well as their circumstances before, during and after their journey, including the human rights violations and risks they face [7-10].

This article explores the current protection possibilities and gaps for Ethiopians and Somalis that have been affected by environmental factors such as drought in their home countries and fled to Yemen. It also gives a brief introduction to disaster-related movement, as well as policy and legal options in cross-border disaster-related displacement in the region in general.

It follows a socio-legal approach, and the research is based on a mixed-methods approach that combines a review of existing literature, laws and policies; interviews with government officials, national and international organizations' representatives and others working on issues closely related to the research topic; and Focus Group Discussions (FGDs) with displaced people. Like any other research work based on observations from the field, there are some limitations that need to be acknowledged, such as issues related to time and funding constraints, accessibility to irregular migrants, security issues impacting on geographic coverage and reactivity of the interviewees [11]. 


\section{CONCEPTUAL BACKGROUND}

According to UNISDR [12], a disaster can be defined as '[a] serious disruption of the functioning of a community or a society involving widespread human, material, economic or environmental losses and impacts, which exceeds the ability of the affected community or society to cope using its own resources'. Moreover, a disaster is a combination of hazard and human vulnerability. Human factors contribute to climate change, which in turn influences the occurrence of certain natural hazards [1]. Moreover, all disasters, including those not related to climate change, are influenced by human factors, such as in the cases where the actions by authorities before, during and after the hazards are weak, insufficient or even directly harmful.

Regarding human mobility in relation to climate change and disasters, most migration experts emphasize that there is a variety of factors that interact leading to human mobility [13-19].

While the majority of displaced people stay within the borders of their countries, some do cross international state borders. Many lawyers and humanitarian experts identify a normative gap here [20]. Based on the refugee definition of the 1951 Convention relating to the Status of Refugees, which requires persecution on certain listed grounds, many conclude that those displaced in the context of natural hazard-related disasters do not qualify for refugee status $[21,20]$. However, our conceptualization of disasters and displacement as involving human factors and being multi-causal may inform a different interpretation and application of refugee law (see also [18]). A socio-legal approach, which is not limited to exploring the law in books but also looks at law in action, may also show that the refugee concept is not entirely irrelevant in the context of climate change and disasters [18].

\section{ETHIOPIA AND SOMALIA AS PART OF THE HORN OF AFRICA}

The Horn of Africa is a region including Eritrea, Djibouti, Ethiopia and Somalia. These countries are inhabited by roughly 103 million people with approximately 87 million in Ethiopia and approximately 9.6 million in Somalia [22]. The Horn of Africa is the poorest region in Africa and struggles with sudden- and slow-onset disasters in addition to political tensions and violent conflicts.

Although the IPCC [23] expects the average rainfall to increase in the region, there may still be long, dry periods with erratic and intense rainfalls. In mid-2011, due to late rainfalls, a massive drought developed in the region. This mainly affected Somalia, northern Kenya, south-eastern Ethiopia and Djibouti [24]. The lack of rain resulted in a famine due to the interaction with the conflicts and political instability as well as other factors [25]. This lead to the displacement of hundreds of thousands of people, to a large extent across borders $[6,26,27,18]$.

\subsection{Ethiopia}

Although Ethiopia has reported economic growth and social welfare improvement throughout the past two decades, development indicators show that it remains one of the poorest and least developed countries in the world, with significant challenges including drought, soil degradation, high inflation and population density [10]. Moreover, violent conflicts and political tensions have exacerbated the difficult situation. To deal with the drought problem, the government has initiated relocation programmes, but these have been criticized. According to Amnesty International [27] and Human Rights Watch [28], there were forced evictions with no consultation with and compensation for the affected communities. Hammond [29] goes 
beyond that by arguing that forced relocation throughout the past three decades has taken place to serve a class system and to support ethnic and religious hierarchies.

\subsection{Somalia}

Somalia's weather conditions vary from semi-arid to arid, with irregular rainfall and moderate temperatures in the north, and high temperatures in the south. Natural hazards include recurring droughts, frequent dust storms over the eastern plains in summer and floods during the rainy season. Since the early 1990s, Somalia has also been suffering from continuous political unrest and conflicts combined with drought, factors that have created severe humanitarian conditions and lead to several parts of the country being declared as famine regions in 2011 [30]. It is among the countries most vulnerable to climate change and natural hazards [31]. More than one million out of a population of less than 10 million are internally displaced, and another million live as refugees in other countries in the region [32]. There have been some recent positive developments in the political and security situation in Somalia, followed by some Somalis returning home.

\section{OVERVIEW OF REASONS AND PATTERNS OF HUMAN MOBILITY}

Massive movements across the African continent have been triggered by droughts combined with population growth, lack of sustainable land and water management, international, regional and domestic political conflicts and tensions [27,33]. Particularly in the Horn of Africa, human mobility has historically been dominated by circular movements, especially among pastoralists [34]. Today, this livelihood and lifestyle is under threat in particular due to restrictions of the international borders, development intervention failures and marginalization in government and development policies [35-37]. In general, there is also a large amount of rural-urban movement [36]. Furthermore, human mobility in the region is not only associated with forced movements but rather mixed migration, which includes various categories of people, such as refugees, economic migrants and others travelling with or alongside each other, using the same routes and means of transport [10].

It is mainly less educated pastoralists and famers who leave Ethiopia irregularly [10]. The main reasons for leaving are decreasing livelihood opportunities in addition to claimed political and ethnic oppression and persecution against Oromos and Ogadenis.

The main reasons for leaving Somalia, and South Central Somalia in particular, include extreme poverty, generalized violence, serious human rights violations and armed conflicts preventing people from accessing basic needs such as food, medical services, health care and livelihoods [10]. Particularly in the year 2011, main reasons included drought and lack of livelihood opportunities and humanitarian assistance [10,38].

In addition to travelling south and north to or through Kenya, Egypt, Israel and Libya, a main route for Somalis and Ethiopians is eastward. Many cross the Gulf of Aden from Bossaso in northeastern Somalia to Yemen. Others travel through Djibouti and arrive at the Red Sea Coast of Yemen. Some remain in Yemen but many move towards Gulf states and elsewhere. The oil economies' labour demand combined with the conflicts and political unrests in the countries of origin have been seen as main reasons for these movements [39].

Many people on the move in the region experience dehydration from heat and lack of water, starvation, physical abuse, rape and sexual violence, road accidents in overfilled open trucks, drowning in overfilled boats, murder, robbery, kidnapping and extortions, and the smugglers themselves are the most common perpetrators of the abuse [10]. Quite often there is a blurry line between human smuggling and trafficking. 


\section{RELEVANT POLICIES, LAWS AND PRACTICES}

\subsection{International environmental law}

The three countries focused on in this study are parties to the 1992 UN Framework Convention on Climate Change [40]. Paragraph 14(f) of the UNFCCC Cancun Agreement invites parties to enhance adaptation by undertaking 'measures to enhance understanding, coordination and cooperation with regard to climate change induced displacement, migration and planned relocation, where appropriate, at the national, regional and international levels' [41,42].

Climate agreements focus on climate change and climate-related events and processes rather than natural hazard-related disasters more in general and resulting displacement. Meanwhile, the Hyogo Framework for Action focuses on disaster risk reduction and management. The 1994 UN Convention to Combat Desertification can be considered another relevant instrument and even includes in article 10.3 (a) 'mechanisms for assisting environmentally displaced persons' [43]. A general challenge with environmental instruments is the poor implementation and lack of individual and group rights [4].

Particularly important in the region is the Intergovernmental Authority on Development (IGAD). IGAD was established by Djibouti, Ethiopia, Kenya, Somalia, Sudan and Uganda through the United Nations for development and drought control. The Regional Consultative Process of IGAD aims at facilitating regional dialogue and co-operation in migration management amongst IGAD Member States, to which Eritrea was added later.

\subsection{International refugee law}

According to article 14 of the 1948 Universal Declaration of Human Rights, everyone has a right to seek asylum. The right to seek asylum on the basis of persecution is also provided for in article 12 of the 1981 African Charter on Human and Peoples' Rights, article 12 in the 1990 Cairo Declaration on Human Rights in Islam as well as article 28 in the 2004 Arab Charter on Human Rights. Moreover, human rights law contains provisions that involve the protection against being sent back to an area where there is a risk of serious rights violations such as torture or inhuman treatment.

The main refugee law instruments that apply in the region are the 1951 Convention relating to the Status of Refugees and its 1967 Protocol, as well as the 1969 African Union (AU) Convention Governing Specific Aspects of Refugee Problems in Africa. As mentioned previously, persecution on certain grounds is a main criterion to qualify as a refugee according to the 1951 Convention. A dynamic and well-informed interpretation of this refugee definition, which would include an appreciation of the human factors and multi-causality of disasters and displacement, can lead to protection for some people fleeing in the context of disasters (see, for example, [18]). The term 'events seriously disturbing public order' in the AU Convention also offers some possibilities for protection, although it has mainly been understood to refer to situations of generalized violence rather than natural hazard-related disasters [44].

Refugee status determination is undertaken by an authority designated by the hosting government or by UNHCR in close cooperation with the government. Sometimes people are designed refugee status on a group basis, the so-called prima facie refugees. This typically occurs when there is no capacity to run individual interviews with all the people who cross the borders due to their large number and/or the reasons why the majority of these people flee are clearly in line with international refugee law.

The principle of non-refoulement bans returning a refugee by force to a place where they face a threat to life or freedom. Since it is considered a rule of international customary law, even the states that are not party to the international conventions are obliged to respect it. 


\subsection{Refugee law and practice in the Horn of Africa}

Except for Eritrea, all the Horn of Africa countries are parties to the 1951 Convention and its 1967 Protocol [45]. Moreover, almost all African states have signed and ratified the 1969 AU Convention [46]. All countries in the Horn and Kenya grant South Central Somalis prima facie refugee status. In terms of local integration, Kenya, Ethiopia and Eritrea do not allow for that $[10,47]$.

\subsection{Refugee law and practice in the MENA region}

Only a few countries of the MENA region are parties to the 1951 Refugee Convention and its 1967 Protocol [48]. Yemen is one of them and has granted prima facie status to Somalis since 1992.

Article 1 of the Arab Convention on Regulating Status of Refugees in the Arab Countries recognizes as refugees those who flee 'because of natural disasters or grave events resulting in major disruption of public order in the whole country or any part thereof'. However, this remains a draft convention, and slow-onset disasters, such as droughts, will not necessarily included in the understanding of 'natural disasters'.

The 2012 Ashgabat Declaration of the International Ministerial Conference of the Organization of Islamic Cooperation on Refugees in the Muslim World also signals a commitment to refugee protection. However, its text is not binding.

\section{CASE STUDY - YEMEN}

There is a long history of seeking and granting exile, trade, proselytizing, inter-marriages and other connections between the Horn of Africa and Yemen [49,50]. However, since the early 1990s, the volume has increased and Yemen has been receiving hundreds of thousands of Ethiopians and Somalis. Out of the MENA-region, it is currently the country with the largest Somali displaced community and the main transit country for Ethiopians.

An estimate indicates that 447,000 people - mostly Ethiopians and Somalis - have set off to Yemen in boats from Djibouti or the Somali port city of Bossaso between 2006 and 2012 [10].

An important reason why it has become easier for people to cross the Yemeni borders as compared with the situation before is the lacking rule of law and border control during the recent and current political unrest and conflict $[9,10]$.

The number of people arriving in Yemen has decreased in the last part of 2013, however, likely due to the strict border controls in Saudi Arabia and emigration restrictions in Ethiopia.

For the purpose of this study, the field research was conducted in Sana'a, Aden and Al-Kharaz refugee camp in November 2013. Fifteen representatives from the government, UNHCR, IOM and other international and national organizations were interviewed. A total of seven FGDs with 5-10 participants were organized in the locations. The group discussions included Somali and Ethiopian refugees, asylum seekers, and regular and irregular migrants.

\subsection{Reasons for moving to Yemen}

According to the Regional Mixed Migration Secretariat, around 8\% of Ethiopian respondents and $14 \%$ of Somali respondents listed drought as the reason for leaving in 2011. According to staff members in UNHCR, the Danish Refugee Council (DRC) and other organizations, many more Ethiopian and Somali farmers and pastoralists probably came because of the drought but may have given other reasons when asked such as seeking better livelihoods or economic opportunities. 
Most Ethiopian participants to the FGDs spoke of ethnic and/or political aspects in addition to the environmental challenges as reasons for leaving. In line with previous studies [9,51], many Oromos and Ogadenis in particular referred to ethnic and politically based discrimination and persecution interacting with droughts and other disasters. Several mentioned how they were not given access to assistance before, during or after disasters.

Somalis reported generalized violence, persecution, lack of humanitarian assistance as well as environmental reasons. However, a group of newly arrived young men in Bassateen mentioned that they had come exclusively due to floods that had recently affected areas in South Central Somalia. Several Somalis mentioned that the lack of livelihood options and the interaction of armed conflict and drought as main reasons for leaving Somalia. Some said they had come mainly because of drought or floods. They had preferred Yemen because it was close geographically and there was freedom of movement as opposed to Kenya where there is encampment of refugees.

\subsection{Regular and irregular status in Yemen: formal laws and mechanisms}

Yemen is party to several human rights treaties and the 1951 Refugee Convention and its 1967 Protocol. Several ministries and governmental institutions are involved in refugee and migrant affairs. The government also co-leads and regularly participates in the Yemen Mixed Migration Task Force. UNHCR, which deals with refugee status determination and refugee assistance, has a close and generally good relationship with the government. However, protection of Ethiopians and Somalis in practice is often difficult in a country like Yemen with several political and economic challenges. As of 1 April 2013, there were 231,064 Somali and 5270 Ethiopian refugees [52].

\subsection{Somali prima facie refugees in Yemen}

Over 90\% of the Somalis seek asylum upon arrival, knowing that they are granted refugee status on a prima facie basis. Although the Yemeni government had indicated in the year 2010 that it would reconsider the automatic refugee status as it believed that many Somalis were economic migrants or terrorists [53], there has been no change in the status, perhaps partly due to the political upheavals in the year 2011. This implies that this special status might not be lasting and that Somalis displaced in the context of disasters might have to deal with challenges of getting protection in the future. They would have to go through individual status determination and show that they risked persecution on one of the recognized Convention grounds.

\subsection{Regular and irregular Ethiopian migrants in Yemen}

Ethiopians as a group in Yemen were for a while considered illegitimate asylum seekers and detained, deported and refouled. One important reason may have been that the Ethiopian government considers seeking asylum illegal and cooperates closely with Yemen [7]. However, some Ethiopians - mostly young females - have an official status as regular labour migrants typically employed for domestic work.

After interventions by UNHCR and other international organizations, the situation of the Ethiopians has improved. Once arriving in Yemen, they are given a grace period of 20 days to apply for asylum at UNHCR. However, many of them prefer to move more or less directly to Saudi Arabia and the Gulf countries. Reasons for this include the search for better livelihoods; the fact that waiting for obtaining an official status in Yemen might take them years 
when compared with the Somalis; the fear of deportation from Yemen to Ethiopia (acceptance rates are around 20\%).

From the stories told during FGDs, several Ethiopians might have valid asylum claims since there were elements of persecution interacting with the drought or other factors back home. Some of the NGO staff members interviewed highlighted that often the Ethiopians especially minors - are lost in translation when describing their situation; instead of reporting about possible persecution they communicate that they are seeking improved livelihoods, which is not recognized as legitimate grounds. Moreover, their networks in Yemen are weak, which reduces their chances to receive appropriate knowledge and information. The UNHCR officials interviewed for this study expressed considerable understanding and sympathy when speaking about people who have left Somalia and Ethiopia in the context of drought and famine. However, when it comes to refugee law application, they find themselves constrained by the 1951 Convention and its criteria. Another constraint is the pressure from Saudi Arabia on Yemen to reduce the number of people entering, and transiting through, the country. As mentioned, among the few Ethiopians who do apply for asylum only about $20 \%$ are accepted.

However, there are also informal institutions related to culture and religion that provide some assistance and protection to Ethiopians and Somalis regardless of formal status. Respect for displaced people and appreciation of those who provide refuge have a particular place in sharia [54]. In Yemen, the local mosque in Bassateen provides much assistance to the Ethiopians and Somalis. In other places, many ordinary Yemenis also try to assist with food, shelter, access to medical care, etc.

A high-level government official, who also mentioned the Islam-based duty and highlighted the good connections between the countries, suggested that bilateral solutions between the disaster-affected country and the hosting country might be a way forward in cases that fall outside the 1951 Convention in the region. Such agreements, he said, could be guided by principles of good neighbourliness and humanitarianism.

\subsection{Basic needs during displacement in Yemen}

The Kharaz refugee camp is the only one in Yemen. It is located near the coast in the southern Lahaj governorate where the environment is harsh and dry and there are few livelihood options. There is freedom of movement, and most refugees live elsewhere.

UNHCR and other organizations give assistance to refugees. Only certain vulnerable groups among Ethiopian asylum seekers receive assistance. The Ethiopian irregular migrants are in an even worse situation. Only the most vulnerable receive the most basic life-saving assistance from organizations such as IOM and DRC.

Ethiopians are also more exposed to traffickers and other types of violation since many lack formal status and are afraid of the authorities in cases of abuse. For the same reason, they are more subject to potential detentions and deportations.

Urban settings are the preferred destinations for Ethiopian and Somali asylum seekers, refugees and migrants. Bassateen in Aden receives the highest number, although it is densely populated and suffering from lack of infrastructure, traffic and sanitary issues. In addition to the local mosque, there are a few organizations providing some assistance here. Most of the refugee-assistance in Yemen is camp-based, however.

In general, the government does not have major objections to organizations supporting migrants and sometimes even encourage them to provide further assistance. Main challenges in migrant assistance include the lacking recognition of migrants among many of the organizations themselves and donors. For example, assistance for migrants is not normally 
considered as qualifying for humanitarian aid funding, although IOM has been able to access some such funding for their life-saving assistance and voluntary returns program for the destitute and stranded migrants on the Saudi-Yemeni border.

Shelter and livelihood were the two most frequently mentioned challenges among Somalis and Ethiopians, including asylum seekers, refugees and irregular migrants. In terms of accessibility to the labour market, the Yemeni government follows a protective policy for its nationals. Many Somalis and Ethiopians survive through begging, work on qat farms, domestic work and other work in the informal sector which typically exposes them to dirty, dangerous and difficult work.

\subsection{Future outlook}

Most of the Ethiopians and Somalis did not consider staying in Yemen as a long-term solution, especially since Yemen itself is suffering from various political, economic and social challenges.

The plans for the future typically involved continuing the journey to Saudi Arabia or the Gulf states, or even to the United States, Canada or Europe (see also [9,50]). Resettlement has become less accessible and is no longer possible to the USA for the Somalis in Yemen. Still, many refugees hope for resettlement. With the recent harsher immigration policies and practices in Saudi Arabia, many were considering returning home and/or using other routes to reach other countries, including Europe.

For return home to be possible, safe and sustainable, Somalis and Ethiopians mentioned that they needed better livelihood options and an improved political and security situation. Recently, thousands of destitute Ethiopian migrants have in fact been returned home. Hundreds of Somalis have also returned after some improvements in their home country.

\section{CONCLUSIONS AND RECOMMENDATIONS}

This article gives a brief introduction to disaster-related movement, as well as policy and legal options in cross-border disaster-related displacement in the Horn of Africa and wider region. It then explores the current protection possibilities and gaps for Ethiopians and Somalis that have been affected by environmental factors such as drought in their home countries and fled to Yemen.

Several Somalis and Ethiopians were influenced in their cross-border movement by natural hazard-related disasters. Quite often the natural factor interacted with other social and political factors in creating a disaster, such as the 2011 drought and famine, as well as triggering displacement (see also [18]). Without exception, the Somalis and Ethiopians mentioned (lack of) livelihood options as one of the main reasons for leaving their homes. The armed conflict and lack of humanitarian access in Somalia played an important role in escalating the drought and famine. Many of the Ethiopians in Yemen mentioned that economic and political marginalization, and even persecution, interacted with drought and other disasters, forcing them to leave their homes. In terms of preventing displacement and facilitating return, this implies that it is important to do more than address climate and environmental factors in isolation; livelihood interventions are necessary and it is crucial to address the complex conflicts and political situations.

In the case of cross-border displacement, a fundamental first challenge is for people to be able to access and enter another country and apply for protection. Many countries, such as Saudi Arabia, are increasingly putting obstacles in the way for asylum seekers with a right to 
seek asylum as well as others with less than clear rights. Related to this, there are hazards of irregular migration, smuggling and trafficking.

The formal refugee or other legal status question may also be a concern. Currently, there are no instruments in force explicitly providing entry, status and rights on the basis of natural hazard-related disasters. This leads many doctrinal lawyers as well as others to conclude that those displaced fall outside protection instruments and that there is a normative gap at the global level. With the conceptualization of disasters and displacement as multi-causal and involving human factors, as well as socio-legal findings from the case study, a different conclusion can be drawn (see also [18]). Somalis in Yemen were in fact considered refugees. While the prima facie status may be volatile, the refugee status is arguably legitimate for many of those displaced in the context of disasters when disasters and displacement are understood and conceptualized correctly.

In other cases people, such as Ethiopians in Yemen, risk falling on the outside of existing protection instruments. For many Ethiopians in Yemen, there were also social and economic obstacles in accessing and succeeding with the asylum process, including a lack of knowledge, resources and adequate vocabulary to present their case. Active legal aid and outreach is necessary. Some cases where there were links to persecution could arguably constitute valid asylum claims.

A socio-legal approach involves a broader concept of law and norms than the doctrinal approach, which is merely focused on formal state law. An important finding from the case study is that Islamic norms may provide assistance in some disaster situations. This finding merits further research.

Two other options are also worth exploring further. As a high-level Yemeni government official suggested, bilateral solutions guided by principles of good neighbourliness and humanitarianism might be a way forward in cases that fall outside current refugee law. Secondly, exploring labour migration channels and potentially expanding these in the wider region might also be a way forward as many of the people moving out from the Horn of Africa are in search of better livelihoods and may not have the immediate neighbouring countries as their ultimate and desired destination.

\section{REFERENCES}

[1] IPCC, Summary for policymakers. Intergovernmental Panel on Climate Change Special Report on Managing the Risks of Extreme Events and Disasters to Advance Climate Change Adaptation, eds. C.B. Field, V. Barros, T.F. Stocker, D. Qin, D. Dokken, K.L. Ebi, M.D. Mastrandrea, K.J. Mach, G.-K. Plattner, S.K. Allen, M. Tignor, P.M. Midgley, Cambridge University Press: Cambridge and New York, 2012.

[2] IDMC, Global Overview 2012: People Displaced by Disasters, IDMC/NRC: Geneva, 2013.

[3] Morrissey, J., Rural-urban migration in Ethiopia. Forced Migration Review, 28(30), pp. $28 \& 29,2008$.

[4] Kolmannskog, V. \&Trebbi, L., Climate change, natural hazard-related disasters and displacement: a multi-track approach to filling the protection gaps. International Review of the Red Cross, 92(879), pp. 713-730, 2010. doi: http://dx.doi.org/10.1017/ S1816383110000500

[5] Zetter, R., Protecting Environmentally Displaced People: Developing the Capacity of Legal and Normative Frameworks, Refugee Studies Centre, Oxford University: Oxford, 2011. 
[6] Afifi, T., Govil, R., Sakdapolrak, P. \& Warner, K., Climate Change, Vulnerability and human Mobility: Perspectives of Refugees from the East and Horn of Africa, Report No. 1, United Nations University Institute for Environment and Human Security: Bonn, 2012.

[7] Human Rights Watch, Hostile Shores: Abuse and Refoulement of Asylum Seekers and Refugees in Yemen, Human Rights Watch: New York, 2009.

[8] Soucy, A., Mixed Migration from the Horn of Africa to Yemen: Protection Risks and Challenges, Danish Refugee Council: Nairobi, 2011.

[9] DRC \& RMMS, Desperate Choices: Conditions, Risks \& Protection Failures Affecting Ethiopian Migrants in Yemen, Danish Refugee Council and Regional Mixed Migration Secretariat: Nairobi, 2012.

[10] RMMS (Regional Mixed Migration Secretariat), Migrant Smuggling in the Horn of Africa and Yemen: The Political Economy and Protection Risks, RMMS: Nairobi. Available from www.regionalmms.org/index.php?id=12.

[11] Jacobsen, K. \& Landau, L.B., The dual imperative in refugee research: some methodological and ethical considerations in social science research on forced migration. Disasters, 27(3), pp. , 2003.

[12] UNISDR (United Nations International Strategy for Disaster Reduction), Terminology. available ar www.unisdr.org/we/inform/terminology, 2009.

[13] EACH-FOR (Environmental Change and Forced Migration Scenarios), Synthesis Report, available at www.each-for.eu, 2009.

[14] Afifi, T. \& Jäger, J., eds., Environment, Forced Migration and Social Vulnerability, Springer: Heidelberg, 2010. doi: http://dx.doi.org/10.1007/978-3-642-12416-7

[15] Foresight, Migration and Global Environmental Change, The Government Office for Science: London, 2011.

[16] UNEP, Livelihood Security: Climate Change, Conflict and Migration in the Sahel. UNEP, 2011. ISBN No: 978-92-807-3198-9.

[17] Martin, S.F. \& Warner, K., Climate change, migration and development, ed., Global Perspectives on Migration and Development: GFMD Puerto Vallarta and Beyond, ed. Irena Omelaniuk, Springer Books: New York, 2012.

[18] Kolmannskog, V., "We are in between": Securing effective rights for persons displaced in the context of climate change and natural hazard-related disasters, Doctoral Thesis, Submitted to the University of Oslo. Introduction available at: www.vikramkolmannskog.no/resources/Intro-to-Doctoral-Thesis.pdf, 2013.

[19] Warner, K. \& Afifi, T., Evidence from 8 countries on how vulnerable households use migration to manage the risk of rainfall variability and food insecurity. Climate and Development. DOI: 10.1080/17565529.2013.835707. doi: http://dx.doi.org/10.1080/17 565529.2013.835707

[20] IASC, Climate Change, Migration and Displacement: Who Will Be Affected? UNFCCC, available at http://unfccc.int/resource/docs/2008/smsn/igo/022.pdf (31 October), 2008.

[21] Falstrom, D.Z., Stemming the flow of environmental displacement: creating a convention to protect persons and preserve the environment. Colorado Journal of International Environmental Law \& Policy 1, 2001.

[22] UNDESA, United Nations, Department of Economic and Social Affairs, Population Division, World Population Prospects: The 2012 Revision, UNDESA, 2012.

[23] IPCC, Climate Change 2007: The 4th Assessment Report of the IPCC, Cambridge University Press: Cambridge, 2007. 
[24] FSNAU, Quarterly Brief - Focus on Post-Deyr 11/12 Season Early Warning, (December), Food Security and Nutrition Analysis Unit: Nairobi, 2011.

[25] Terefe, H.A., People in crises: tackling the root causes of famine in the Horn of Africa. Discussion Paper No. 1-2012, Norwegian Agricultural Economics Research Institute: Oslo, 2012.

[26] Leighton, M., Desertification and migration, Governing Global Desertification: Linking Environmental Degradation, Poverty and Participation, eds. P.M. Johnson, K. Mayrand, M. Paquin, Ashgate: Aldershot, 2006.

[27] Amnesty International, The State of the World's Human Rights, Amnesty International: London, 2013.

[28] Human Rights Watch, World Report 2013, Human Rights Watch: New York, 2013.

[29] Hammond, L., Governmentality in motion: 25 years of Ethiopia's experience of famine and migration policy. Mobilities, 6(3), 2011. doi: http://dx.doi.org/10.1080/17450101.2 011.590038

[30] FSNAU, \& FEWSNET, Famine Thresholds Surpassed in Three New Areas of Southern Somalia, FSNAU, \& FEWSNET: Nairobi/Washington (3 August), 2011.

[31] Global Humanitarian Forum, The Anatomy of a Silent Crisis. Global Humanitarian Forum: Geneva, available at: www.preventionweb.net/files/9668_humanimpactreport1. pdf, 2009.

[32] NRC, Flyktningregnskapet, NRC: Oslo, 2013.

[33] Keller, E.J., Drought, war, and the politics of famine in Ethiopia and Eritrea. Journal of Modern African Studies, 30(4), 1992. doi: http://dx.doi.org/10.1017/ S0022278X00011071

[34] Afifi, T., Liwenga, E. \& Kwezi, L., Rainfall-induced crop failure, food insecurity and out-migration in Same-Kilimanjaro, Tanzania. Climate and Development, 2013. DOI: 10.1080/17565529.2013.826128. doi: http://dx.doi.org/10.1080/17565529.2013.826128

[35] Ahmed, A.G.M., Azeze, A., Babiker, M. \& Tsegaye, D., The Post-Drought Recovery Strategies among the Pastoral Households in the Horn of Africa: A Review, OSSREA: Addis Ababa, 2002.

[36] Bakewell, O. \& De Haas, H., African migrations: continuities, discontinuities and recent transformations, African Alternatives, eds. P. Chabal, U. Engel, L. de Haan, Brill: Leiden, 2007.

[37] Nori, M., Taylor, M. \& Sensi, A., Browsing on fences: pastoral land rights, livelihoods and adaptation to climate change. IIED Paper No. 148, 2008.

[38] Kolmannskog, V., Gaps in Geneva, gaps on the ground: case studies of Somalis displaced to Kenya and Egypt during the 2011 drought. New Issues in Refugee Research, 2012.

[39] Thiollet, H., Migration as diplomacy: labor migrants, refugees, and Arab regional politics in the oil-rich countries. International Labor and Working-Class History, 79, 2011.

[40] UNFCCC, Parties to the Convention and Observer States, available at http://unfecc.int/ parties_and_observers/parties/items/2352.php, 2013.

[41] UNFCCC, Cancun Agreements FCCC/CP/2010/7/Add.1, available at http://cancun.unfccc.int, 2011.

[42] Warner, K., Human Migration \& Displacement in the Context of Adaptation to Climate Change: Cancun Adaptation Framework and Potential for Future Action. Environment \& Planning C: Government \& Policy Managing Editors: Andrew Jordan and Andres Rodriguez-Pose, eds Robert Bennett, Gillian Bristow, Harriet Bulkeley, Jonathan Hopkin, Richard Perkins, Henrik Selin, Fulong Wu, 2012. 
[43] UNCCD, Status of Ratification, Available at www.unccd.int/en/about-the-convention/ the-convention/Status-of-ratification/Pages/default.aspx.

[44] Rankin, M.B., Extending the limits or narrowing the scope? Deconstructing the OAU refugee definition thirty years on. New Issues in Refugee Research, Working Paper No. 113, UNHCR: Geneva, 2005.

[45] UN, United Nations Treaty Collection, available at http://treaties.un.org, 2013.

[46] ACHPR (African Commission for Human and Peoples' Rights), Ratification Table: AU Convention Governing Specific Aspects of Refugee Problems in Africa, Available at www.achpr.org/instruments/refugee-convention/ratification, 2013.

[47] UNHCR East and Horn of Africa, 2013 UNHCR Regional Operations Profile - East and Horn of Africa, available at www.unhcr.org/pages/49e45a846.html, 2013.

[48] UNHCR MENA, 2013 UNHCR Country Operations Profile - Middle East and North Africa (MENA), available at www.unhcr.org/pages/4a02db416.html, 2013.

[49] Martin, B.G., Arab migrations to East Africa in Medieval times. International Journal of African Historical Studies, 7(3), 1974. doi: http://dx.doi.org/10.2307/217250

[50] De Regt, M., Migration to and through Yemen: the case of migrant domestic workers. Paper Prepared for the Migration and Refugee Movements in the Middle East and North Africa, The Forced Migration \& Refugee Studies Program, The American University in Cairo, Egypt, 23-25 October 2007.

[51] Soucy, A., Mixed Migration from the Horn of Africa to Yemen: Protection Risks and Challenges, Danish Refugee Council: Nairobi, 2011.

[52] UNHCR Yemen, Yemen Factsheet April 2013, available at www.unhcr.org/4c907a4a9. html, 2013.

[53] IRIN, Somalis Set to Loose Automatic Refugee Status, available at http://m.irinnews. org/report/90103/yemen-somalia-somalis-set-to-lose-automatic-refugee-status\#.UswE-fYswgF, 2010.

[54] Rahaei, S., The rights of refugee women and children in Islam. Forced Migration Review (June 2012, revised edition), 2012.

$\begin{array}{ll}\text { AU } & \text { African Union } \\ \text { DRC } & \text { Danish Refugee Council } \\ \text { EPRDF } & \text { Ethiopian People's Revolutionary Democratic Front } \\ \text { IOM } & \text { International Organization for Migration } \\ \text { MENA } & \text { Middle East and North Africa } \\ \text { NRC } & \text { Norwegian Refugee Council } \\ \text { OLF } & \text { Oromo Liberation Front } \\ \text { ONLF } & \text { Ogaden National Liberation Front } \\ \text { RMMS } & \text { Regional Mixed Migration Secretariat } \\ \text { UNFCCC } & \text { UN Framework Convention on Climate Change } \\ \text { UNHCR } & \text { United Nations High Commissioner for Refugees }\end{array}$

